\title{
Evaluation of Hefei, Nanjing and Wuhan Tourism Competitiveness
}

\author{
DU Juan, WANG Haitao* \\ School of Environmental and Energy Engineering, Anhui Jianzhu University, Hefei 230601, China
}

\begin{abstract}
Current study made a contrastive analysis of the tourism competitiveness of Hefei, Nanjing and Wuhan by using AHP method associated with establishing a tourism competitiveness index system. The differences of their tourism competitiveness and the decisive factors for that were discussed. The conclusions will be used as the scientific basis for future decision-making concerning the improvement of Hefei overall tourism competitiveness.
\end{abstract}

\section{Introduction}

At present, urban tourism has become the theme of modern tourism. Therefore, the study of urban tourism cannot be ignored. Urban tourism competitiveness is an important part of urban competitiveness and a source of sustainable development for urban tourism. The competitiveness of urban tourism is related to the endowment of tourism resources. It is restricted by various factors such as the management strategy of tourism enterprises, the management level of tourism departments, economic development status, political situation and social security, and urban cultural environment ${ }^{[1]}$. This paper gives an objective evaluation of the tourism competitiveness of Hefei, Nanjing and Wuhan by establishing a comprehensive evaluation index system, and finds the differences in tourism competitiveness of the three cities and the decisive factors that lead to the difference, in order to improve Hefei City. The overall competitiveness of tourism proposes a scientific basis for decision-making.

\section{Study area}

Hefei, Nanjing and Wuhan are the capital cities. The tourism industry has strong complementarity, broad development prospects and good cooperation potential. With a long history, Hefei is a city of harmony between nature and humanity, history and modernity. Nanjing is one of the ancient capitals of the Six Dynasties. It has both natural landscapes and historical relics. Wuhan has the advantage for convenient transportation location and the advantage of opening international routes. It has long been known as the "Nine Provinces Wanted". With the in-depth implementation of the strategy of the rise of Central China, tourists at home and abroad continue to pay attention to tourism along the Yangtze River. How to better integrate resources, make full use of favorable conditions, strengthen regional cooperation, and achieve complementary advantages become the common theme of the three places ${ }^{[2-3]}$.

\section{Tourism competitiveness evaluation index system}

Choosing effective evaluation indicators and constructing a reasonable and complete evaluation index system of tourism competitiveness is the premise and basis for correctly evaluating tourism competitiveness. The establishment of the urban tourism evaluation index system is a comprehensive work, which requires many considerations and arrangements. Based on the specific situation of tourism in Hefei City, this paper divides the tourism competitiveness evaluation index system into urban tourism competition performance, urban tourism competition potential and urban tourism environment support. Each subsystem is divided into several secondary and tertiary indicators. Finally, 24 subdivision indicators are determined to evaluate the tourism competitiveness of Hefei ${ }^{[4-5]}$.

\section{Tourism competitiveness research and evaluation methods}

\subsection{Selection of samples}

This paper selects Nanjing and Wuhan as the comparative analysis cities with Hefei, mainly because the three cities are typical tourist cities in the middle and lower reaches of the Yangtze River, and also the provincial capitals. Through empirical analysis, they can choose the tourism development strategy of Hefei. Provide evidence. Moreover, the three cities are relatively close in space, frequent in connection, and economically developed. They have similar tourism core

\footnotetext{
* Corresponding author: wht@ahjzu.edu.cn
} 
attractions, making comparative analysis more targeted.

\subsection{Determination of the weight of indicators at each level}

The determination of index weight is an important part of evaluation. Because there are many factors affecting the competitiveness of urban tourism and the relationship is complicated, this paper uses AHP to determine the weight of indicators to improve the systematic evaluation. After establishing the hierarchical structure model, constructing the judgment matrix and consistency test, the weight values of the indicators at each level are obtained ${ }^{[6-8]}$.

This paper divides the evaluation index system of urban tourism competitiveness into four layers (Table 1). According to the methods and steps of the AHP method described above, the judgment matrix is constructed by integrating multiple experts to obtain the criterion layer index weight of the urban tourism competitiveness evaluation index system, and after the consistency test, the tourism performance competitiveness and the weight of the tourism environment support force are 0.2 , the weight of the tourism competitiveness is 0.6 . The sub-criterion layer and the basic-index layer are classified according to their importance according to their importance, and the percentage of the layer is determined by multiplying the percentage of the above layer by the percentage. The weight of each specific indicator of the sub-criterion layer and the basic-index layer, such as the percentage of overseas tourists in this layer is 0.055 , and the weight value of the upper city tourism performance competitiveness is 0.2 , according to the above method, the weight value of the overseas tourist number is $0.011^{[9-10]}$.

\subsection{Dimensionless index}

Since the physical meanings of the indicators are different, it is determined that the indicator data cannot have a unified dimension, and the unified assessment cannot be performed. Therefore, the collected indicators are not quantified, and the conversion formula ${ }^{[11-12]}$ is:

$$
P_{i}=10 \times D_{i} / \sum_{i=1}^{n} D_{i}
$$

In this formula, $\mathrm{Pi}$ is a dimensionless index after conversion of an index, $\mathrm{Di}$ is the index value before conversion, and $\sum \mathrm{Di}$ is the sum of the indicators in all evaluation cities ${ }^{[13-14]}$.

Table 1 The index system of city tourism competitiveness

\begin{tabular}{|c|c|c|c|}
\hline Target Layer & Criterion layer & Sub-criterion layer & Basic-index layer \\
\hline \multirow{24}{*}{$\begin{array}{c}\text { Tourism } \\
\text { competitive- } \\
\text { ness }\end{array}$} & \multirow{11}{*}{$\begin{array}{l}\text { Tourism competition } \\
\text { potential }\end{array}$} & \multirow{4}{*}{$\begin{array}{l}\text { Tourist resource } \\
\text { conditions }\end{array}$} & Tourism resource grade \\
\hline & & & Tourism resource monopoly \\
\hline & & & Tourism resource richness \\
\hline & & & Tourism resource awareness \\
\hline & & \multirow{4}{*}{$\begin{array}{l}\text { Tourism economic } \\
\text { conditions }\end{array}$} & Geographic conditions \\
\hline & & & Per Capita GDP \\
\hline & & & Per capita disposable income \\
\hline & & & Residents travel expenses \\
\hline & & \multirow{3}{*}{$\begin{array}{l}\text { Tourism technology } \\
\text { talent }\end{array}$} & $\begin{array}{c}\text { Number of normal high school } \\
\text { students }\end{array}$ \\
\hline & & & $\begin{array}{c}\text { Number of ordinary colleges and } \\
\text { universities }\end{array}$ \\
\hline & & & $\begin{array}{l}\text { Number of tourism industry } \\
\text { personnel }\end{array}$ \\
\hline & \multirow{9}{*}{$\begin{array}{l}\text { Tourism environment } \\
\text { support }\end{array}$} & \multirow{4}{*}{$\begin{array}{c}\text { Tourism natural } \\
\text { environment }\end{array}$} & Per capita green area \\
\hline & & & Urban greening coverage \\
\hline & & & $\begin{array}{l}\text { Industrial waste water discharge } \\
\text { compliance rate }\end{array}$ \\
\hline & & & $\begin{array}{l}\text { Comprehensive utilization of } \\
\text { industrial solid waste gas }\end{array}$ \\
\hline & & \multirow{3}{*}{$\begin{array}{l}\text { Urban tourism basic } \\
\text { function }\end{array}$} & Annual passenger traffic \\
\hline & & & Bus popularity \\
\hline & & & Number of star hotels \\
\hline & & \multirow{2}{*}{$\begin{array}{l}\text { Urban tourism human } \\
\text { environment }\end{array}$} & Residents' attitude towards tourists \\
\hline & & & Urban tourism policy environment \\
\hline & \multirow{4}{*}{$\begin{array}{l}\text { Tourism performance } \\
\text { competitiveness }\end{array}$} & & Number of overseas visitors \\
\hline & & & $\begin{array}{c}\text { Number of visitors from Hong } \\
\text { Kong, Macao and Taiwan }\end{array}$ \\
\hline & & & Star hotel revenue \\
\hline & & & $\begin{array}{l}\text { International tourism foreign } \\
\text { exchange income }\end{array}$ \\
\hline
\end{tabular}

Note: There are two columns in the sub-criterion layer and basic-index layers: the first column is the percentage of the indicator in the layer, and the second column is the weight of the indicator at the layer. 


\subsection{Calculation method of comprehensive competitiveness}

Substitute the weights and score values of each evaluation indicator into the mathematical model of the weighted summation calculation:

$$
F=\sum_{i=1}^{n} W_{i} P_{i}
$$

Among them, $\mathrm{F}$ is the comprehensive competitiveness of urban tourism, $P_{i}$ is the index after dimensionless, and $\mathrm{W}_{\mathrm{i}}$ is the weight value ${ }^{[15]}$.

\section{Comparative analysis of tourism competitiveness between Hefei, Nanjing and Wuhan}

According to the non-class quantitative processing method introduced in the previous article, the indicators of Hefei, Nanjing and Wuhan are transformed, and the dimensionless index value of urban tourism competition performance is obtained, and then weighted and summed to obtain the comprehensive score and ranking of urban tourism competitiveness ${ }^{[16]}$.

Table 2 Comprehensive score of city tourism competitiveness

\begin{tabular}{|l|c|l|l|}
\hline \multicolumn{1}{|c|}{ City } & $\begin{array}{c}\text { He } \\
\text { fei }\end{array}$ & $\begin{array}{l}\text { Nanj } \\
\text { ing }\end{array}$ & $\begin{array}{l}\text { Wu } \\
\text { han }\end{array}$ \\
\hline $\begin{array}{l}\text { Tourism } \\
\text { competition } \\
\text { potential } \\
\text { score }\end{array}$ & $\begin{array}{c}1.4 \\
6\end{array}$ & 2.24 & 2.37 \\
\hline $\begin{array}{l}\text { Tourism } \\
\text { environmen } \\
\text { t support } \\
\text { score }\end{array}$ & 0.6 & 0.73 & 0.62 \\
\hline $\begin{array}{l}\text { Tourism } \\
\text { competition } \\
\text { performanc } \\
\text { e score }\end{array}$ & 0.1 & 1.36 & 0.50 \\
\hline $\begin{array}{l}\text { Comprehen } \\
\text { sive score } \\
\text { of tourism } \\
\text { competitive } \\
\text { ness }\end{array}$ & 1.0 & 1.76 & 1.64 \\
\hline Ranking & 3 & 1 & 2 \\
\hline
\end{tabular}

\section{Conclusions}

From the comparison of evaluation results (Table 2), comprehensive tourism competitiveness in Hefei is located at the end of the three cities, tourism competition performance and tourism competition potential are significantly weaker than Nanjing and Wuhan, the tourism environment supports force is slightly stronger than Wuhan, slightly worse than Nanjing.

In the last, Hefei has only a large advantage in the number of colleges and universities and the number of ordinary institutions of higher learning, which is also consistent with Hefei's reputation as a national "science and education city". Through comprehensive comparison, Hefei has a certain gap compared with the cities of Wuhan and Nanjing, especially in terms of tourism resources and tourism economic conditions.

In terms of tourism environment support, the scores of the three cities are roughly equal, Nanjing ranked first, while Hefei and Wuhan ranked second and third with smaller gaps. In terms of urban tourism and natural environment, the per capita green area of Hefei is slightly lower than that of Wuhan, which is higher than that of Wuhan. The green coverage area has been built far more than the other two cities, which is consistent with the title of "garden city" owned by Hefei. Hefei's industrial wastewater discharge compliance rate is slightly higher than that of Nanjing, slightly lower than Wuhan; the comprehensive utilization rate of solid waste is slightly higher than that of Wuhan, lower than Nanjing, and these two areas need to be further improved.

In terms of the tourism performance, the comprehensive scores and indicators of Hefei's tourism competition performance are smaller than other cities, indicating that the city's tourism performance is less competitive.

\section{Acknowledgment}

This work is supported by the Key Research and Development Special Project of Anhui province of China (201904a07020072).

\section{References}

1. Babak Boroomand, Ali Kazemi, Bahram Ranjbarian. Designing a Model for Competitiveness Measurement of Selected Tourism Destinations of Iran (The Model and Rankings). Journal of Quality Assurance in Hospitality \& Tourism.2019, 20(4): 491-506.

2. Hossein Nazmfar Ali Eshghei Sarideh Alavi Samereh Pourmoradian. Analysis of travel and tourism competitiveness index in middle-east countries. Asia Pacific Journal of Tourism Research.2019, 24(6): 501-513.

3. Antonio García-Sánchez, David Siles, María de Mar Vázquez-Méndez. Competitiveness and innovation: effects on prosperity. Tourism Journal. 2019, 30(2): 200-213.

4. SunYa-Yen. Global Value Chains and National Tourism Carbon Competitiveness. Journal of Travel Research. 2019, 58(5): 808-823.

5. Marketa Kubickova, Seung Hyun Lee. Cuba Today: An Overview of Tourism Competitiveness. Tourism Planning \& Development.2018,15(3): 239-259.

6. China Tourism Statistics Yearbook. China Tourism Press. 2012-2018.

7. Renata Krukowska, Andrzej Świeca. Tourism Function as an Element of Regional Competitiveness. Polish Journal of Sport and Tourism,2018,25(2):32-43. 
8. Xiaoli Jiao, Rongjie He, Wei Song, Jing Li. Measurement and difference analysis on tourism competitiveness of Blue Economic Zone. IOP Conference Series: Materials Science and Engineering.2018,423(1): 012004 (6pp).

9. Jean-Luc Pradel Mathurin Augustin, Shu-Yi Liaw. Tourism competitiveness index of the Asia-Pacific region through consistency analysis.2017, 22(12):1295-1307.

10. Marketa Kubickova. The impact of government policies on destination competitiveness in developing economies. Current Issues in Tourism.2019, 22(6):619-642.

11. Mafalda Gómez-Vega, Luis César Herrero-Prieto. Achieving tourist destination competitiveness: Evidence from Latin-American and Caribbean countries.2018, 20(6):782-795.

12. Dokuz Eylul Univ, Sch Tourism \& Hospitality Management, Izmir, Turkey. Competitiveness and tourism. Journal of tourism and cultural change.2016,14(1):80-81.

13. Zoran Kovačević Igor Mladenović. Planning and Developing Human Resources as a Factor of Improving the Competitiveness of Montenegrin Nautical Tourism. Economic Themes. 2018, 56(2):269-281.

14. Jae-Woo Choi, Research on the Analysis of the Competitiveness of the Medical Tourism of Korea Through IPA. Journal of Engineering \& Applied Sciences.2018, 13(3):721-726.

15. Huang Y L, Li F, Zheng J Q, et al. Research about space structural system in tourism competitiveness around cities in the pearl River Delta. Geographical Research. 2006,25(4):730-740(in Chinese).

16. Antonio García-Sánchez David Siles María de Mar Vázquez-Méndez. Innovation, Competitiveness and Prosperity: A Factor Analysis of Innovation Indicators in Spain. Management Studies. 2018,6(5). 